\title{
Technological Revolutions in Agriculture: Implications for the reshaping of rural economy and society
}

\author{
Anthony Sorensen
}

\begin{abstract}
We identify many current and impending technologies that are likely to impact dramatically on most aspects of rural economy, society and environment, even in the short term. As a result, two of society's major looming problems are (a) how best to accelerate the uptake of beneficial technologies while (b) helping individuals, communities or places damaged by the likely course of events - for example by updating people's skill sets and revising their ambitions and preferences. The increasing problem for governments, communities and businesses alike is that we have limited knowledge of future economic and social trajectories driven by such technologies. Thus, traditional blue-print planning will be increasingly redundant and effective paths to the future will require intensive and inclusive debate and discussions surrounding best options which, along with strong leadership, will help fashion creative, flexible and adaptive cultures. Given geographical diversity in resources it is quite possible that emergent optimal strategies will vary from place to place.
\end{abstract}

Keywords - technology, rural economic and social transformation, creating flexible and adaptive cultures, assisting those people and places potentially harmed by economic and social change.

\section{INTRODUCTION}

$\mathrm{T}$ omorrow, and tomorrow, and tomorrow, creeps in this petty pace from day to day to the last syllable of recorded time. And all our yesterdays have lighted fools the way to dusty death. Out, out, brief candle! Life's but a walking shadow, a poor player that struts and frets his hour upon the stage and then is heard no more. It is a tale told by an idiot, full of sound and fury,

Received: 01-12-2017, Accepted: 22-12-2017; Published: 30-6-2018

Anthony Sorensen, University of New England (Australia)

Email: Tony.Sorensen@une.edu.au signifying nothing." William Shakespeare (1606), Macbeth: Act V, Scene V.

Shakespeare might have penned this famous soliloquy more than 400 years ago, but it is relevant to our emerging world in which the past is increasingly no guide to the future. Numerous current and impending technologies will likely reshape dramatically most aspects of agricultural production in coming decades across many countries, whether developed or developing. My focus here is to outline briefly some of those technologies and explain how they could impact on many different dimensions of agriculture and dependent communities. Every aspect of the industry is faces profound revision, including commodities produced, inputs required, plant and animal genetics, day to day husbandry, farm management practices, capital needs and supply, scale of production, equipment needs, and logistics required in delivering produce to processors and final markets. In the process, many current jobs in the industry will be destroyed, albeit replaced by new ones with often enhanced knowledge and skill sets. Moreover, many of those technologies are barely controllable by agricultural producers, the communities in which they are embedded, and even governments so that resulting changes are likely to impact rural society drastically, irreversibly and with accelerating high speed.

My purpose here is not to make specific forecasts, but to alert agricultural producers to a tsunami of potential changes, most of which will be complexly interconnected and in many ways unforeseen. The greatest challenge to the farm sector, governments and surrounding communities will likely be to adjust their mindsets in such a way that they will be able to deliver innovative, agile and appropriate responses to the innumerable opportunities and threats they will encounter. And this, in effect, means adopting the 
kinds of business and community cultures found in many of the world's high-tech hot-spots, such as Silicon Valley, Seattle, Boston or Tel Aviv. So farmers will increasingly need to:

Embrace learning about new technologies;

Develop the skills necessary to experiment with them;

Become much more risk accepting rather than attached to traditional ways of doing things;

Pay attention to raising the necessary venture or investment capital; and

Mutually assist each other in many different ways - including co-owning machinery and equipment and engaging in what has been termed the sharing economy.

The upside of working in a fast-adapting and future oriented agriculture is likely be greatly increased rural income and wealth and, in the process, the reconfiguration of rural economy and society.

\section{TECHNOLOGIES - IMMINENT \& PROSPECTIVE}

Table 1 lists ten technological arenas that are themselves internally complex and fast developing. This list has been compiled from an extensive literature that asserts, without exception, that those arenas are not separate but rather mutually interacting, thereby spinning off unexpected 'derived' technologies through blending, fusion and integration of the diverse strands. Such integration is accelerating fast simply because the world's technological experts are becoming more intensely networked and mutual engaged. Networking is enhanced through concentration of young, knowledgeable and entrepreneurial people in technology hubs and, in the case of rural society, through the spread of high-speed broadband. Relevant literature informing this discussion includes Brockman (2017), Baldwin (2016), Brynjolfsson and McAfee (2014), Diamandis and Kotler (2012), Ford (2009), Hammersley (2012), Heck and Rogers (2014), Leonard (2016), Mills (2013), Ross (2016), Susskind and Susskind (2016), Wadhwa and Salkever (2017), de Waele (2014), and Wood (2014). This recent work is aweinspiring and revolutionary. It not only documents numerous technologies, but assesses their potential impact on all dimensions of economy and society over the next few years. Likewise, many of these authors debate how technology might be steered and harnessed for the public good alongside its power of disruption.

The University of New England, where I work, is one of Australia's leading agricultural research institutions. That is hardly surprising that it is embedded in the small city of Armidale, whose population is about 25,000 and which is located in a geographically remote farming region over $500 \mathrm{~km}$ from the NSW state capital, Sydney. This location has enabled me to discuss innovative agricultural technologies with local world-leading experts, but also discuss evolving farm practices with leaders in business management and economics. This work has also been aided by a string of Australian national competitive grants over the last decade or so, and these have focused on cotton production, animal husbandry, broadacre grain farming, and even the poultry industry.

Some of major advances using current and impending technologies encountered in this work include:

1. Data gathering though, for example:

a. Probes designed to measure soil moisture and soil nutrients (see Figure 1)

b. Ear-tags monitoring animal health and growth,

c. Systems for monitoring plant and tree growth,

d. Use of drones to monitor feeding patterns of animals in fields, or map the spatial incidence of weeds or patterns of plant growth using cameras attuned to the different colour spectrums of various plants, and

e. Data-loggers on harvesting equipment to map the quantity of grain produced in different parts of fields.

Such data are typically transmitted to farm managers immediately and regularly via the internet, enabling up-to-date assessment of the quality and quantity of farm production. To these one can add a large mass of financial data, including fluctuations in commodity prices; costs of machinery and equipment; transport and processing costs; the prices of such inputs as seed, fertiliser, or animals purchased in; and the cost of workers' wages. Statistical algorithms can then evaluate farm economic performance regularly from all this 'big data', and even sketch future 
TẠP CHÍ PHÁT TRIẺN KHOA HỌC \& CÔNG NGHẸ:

CHUYÊN SAN KHOA HỌC XÃ HộI VÀ NHÂN VĂN, TẬP 2, SỐ 2, 2018

national or global supply and demand scenarios to assist farm decision-making.

Table 1. Ten Tranformative Technologies

\begin{tabular}{|c|c|}
\hline 1 & $\begin{array}{l}\text { Enhanced Information and Communications Technology (ICT), providing improved access to data, information, advice, networking with } \\
\text { others; + Human Augmentation (wearable ICT, surgical implants as foreseen by Kurzweil) leading to cheaper and more pervasive access to } \\
\text { data, information, services, and their analysis; + expansion of E-Services (e-tailing, e-professional services, e-education, and e- } \\
\text { governance providing for cheaper and better quality supplies of these services) }\end{array}$ \\
\hline 2 & $\begin{array}{l}\text { Big Data and Algorithms for its Analysis, leading to quicker and more accurate interpretation of processes and performance + } \\
\text { recommendations for action; + Robotics / Artificial General Intelligence leading both to the replacement of human labour and the } \\
\text { enhancement of human skills }\end{array}$ \\
\hline 3 & Quantum Computing, leading to greater processing speeds and better internet se curity \\
\hline 4 & $\begin{array}{l}\text { Improved Transport (e.g. multi-purpose drones; driverless cars, trucks, or public transport; Elon Musk's hyperloop; and aerospace) } \\
\text { enabling faster, more reliable and cheaper mobility }\end{array}$ \\
\hline 5 & $\begin{array}{l}\text { New Materials (such as graphe ne and stanene which are light weight, high strength, anti-corrosive, good malleability, etc.) leading to } \\
\text { better quality and cheaper machinery, buildings, transport; + Automated Construction Techniques (e.g. look up DIRT in Calgary) greatly } \\
\text { reducing the cost of, and time for, construction }\end{array}$ \\
\hline 6 & $\begin{array}{l}\text { New Foods (e.g. synthetic meat printed on 3-D printers; chem ical cuisine (or Note-by-Note cooking); synthetic milk; prote in from } \\
\text { harvesting insects) providing enhanced competition for existing food and fibre producers, and their potential transfer to new } \\
\text { commodities or to smarter/more competitive production techniques }\end{array}$ \\
\hline 7 & $\begin{array}{l}\text { Smart Everything: agriculture, mining, homes, vehicles, cities -employing a huge array of se nsors linked via the Internet of Things (IOT), } \\
\text { providing better quality and cheaper goods and services and reducing consumption or materials and energy; in agriculture we may also } \\
\text { see inten sive vertical farming employing hydroponics and artificial lighting }\end{array}$ \\
\hline 8 & $\begin{array}{l}\text { FinTech (including crowd-fund ing; venture capital specialists; blockchain; improved investment algorithms), enabling improved access to } \\
\text { necessary capital for investment in farm enterprises }\end{array}$ \\
\hline 9 & $\begin{array}{l}\text { Renewable Energy Generation and Storage: (the latter using new batte ry technologies) and new forms of baseload power - perhaps also } \\
\text { micro-nuclear, enabling cheaper and more reliable supplies of fam energy }\end{array}$ \\
\hline 10 & $\begin{array}{l}\text { Bio-Medical - including cures for many common diseases; surgical advances - leading to rapid advance in life-expectancy; genetic } \\
\text { modification of plants and ani mals, with potentially strong productivity implications }\end{array}$ \\
\hline
\end{tabular}

Source: The Author: items in no particular order

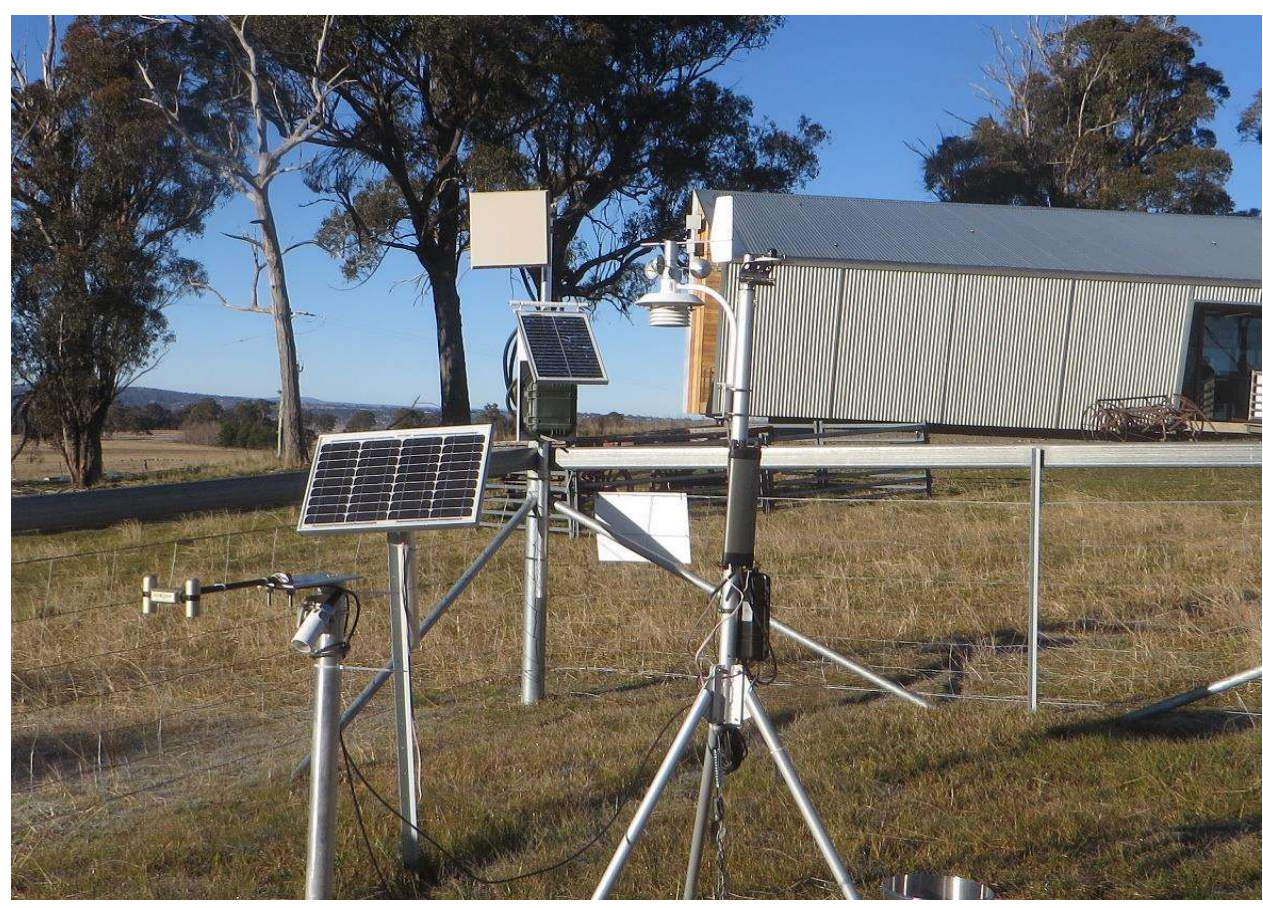

Figure 1. Various types of Automatic Probes and Sensors - University of New England SMART Farm 
2. Use of robots to, for example:

a. Pick fruits - whether citrus, apples, or grapes,

b. Till vegetables (see the horticobot in Figure 2), or

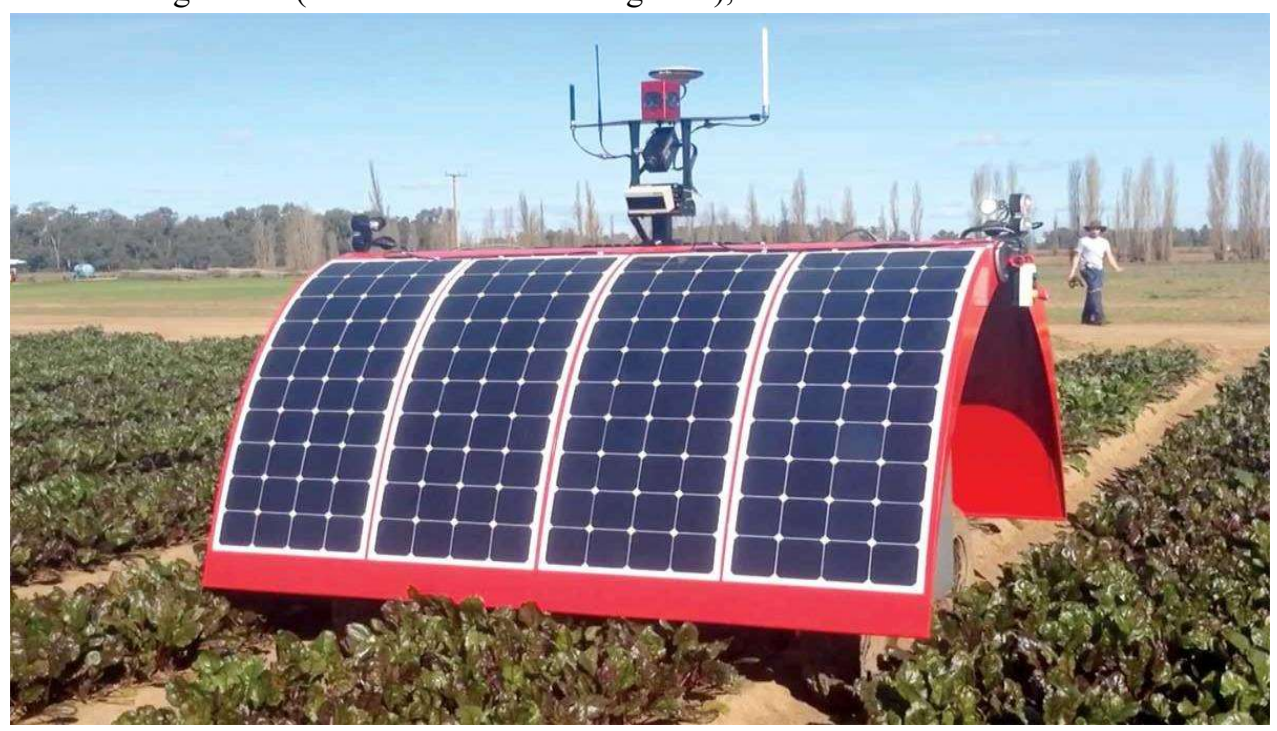

Figure 2. Horticobot

Source: Australian Centre for Field Robotics: http://www.acfr.usyd.edu.au/

c. Even act as sheep-dogs or shepherds for groups of animals (Figures 3 and 4).

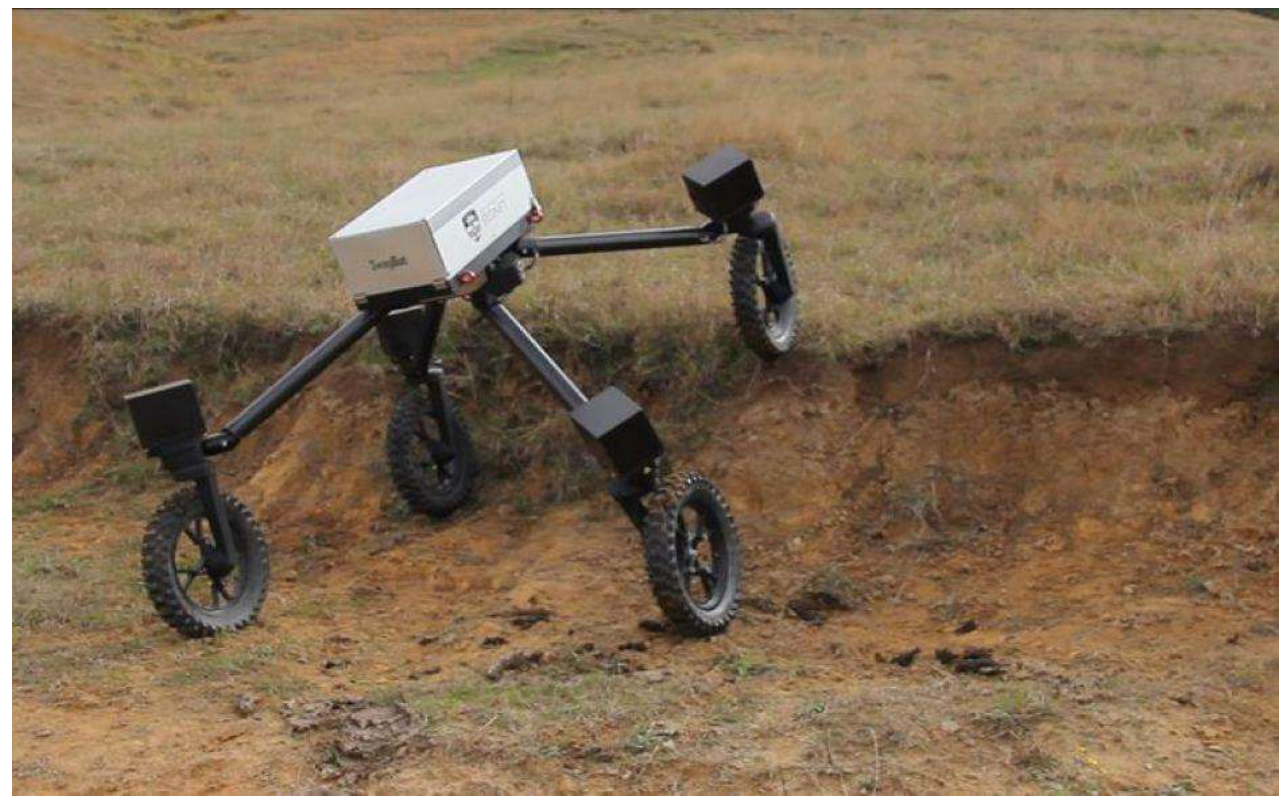

Figure 3. Swagbot - an automated sheep-dog

Source: Australian Centre for Field Robotics: http://www.acfr.usyd.edu.au/ 


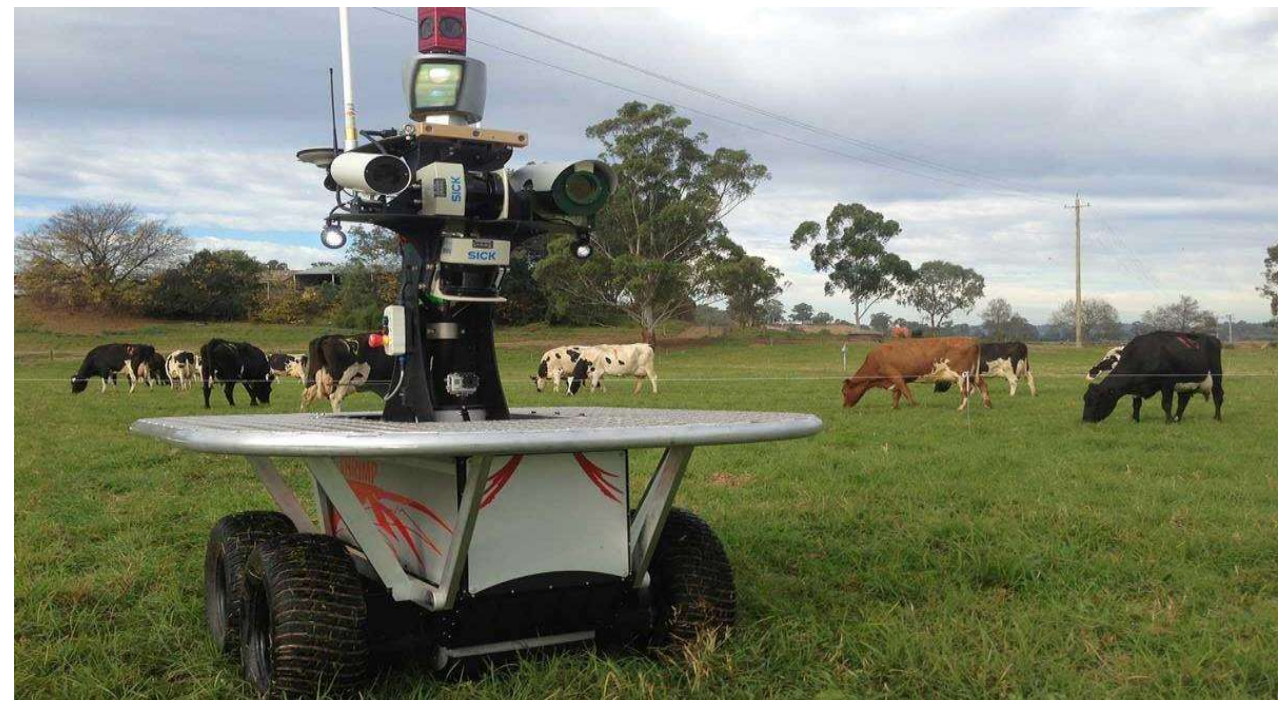

Figure 4. Robot Shepherd

Source: https://www.google.com.au/search? q=Robot + Shepherd\&tbm

It is likely that robots will increasingly be equipped with artificial intelligence to enable them to make informed decisions about performing those tasks more efficiently and effectively without human instruction.

3. Virtual fencing - using light or sound barriers to constrain the movements of sheep and chickens. In the latter case, this could remove the need to cage chickens in tin sheds and thereby make the birds free-range with robots following hens to pick up the eggs they lay.

4. Use of driverless tractors for tilling soil, planting crops, spraying weeds, and harvesting.

5. Genetic engineering, including the interbreeding of livestock and modification of plants to better suit them to particular ecosystems or to withstand various kinds of pests or climatic events.

6. Increasing energy self-sufficiency for farm enterprises and their local rural service centres using a combination of renewables, bio-fuels, and improved storage methods.

7. The emergence of intensive vertical farming close to cities where artificial heating and lighting may deliver multiple crops over the course of a year, while sustainably recycling water and plant nutrients.

\section{POTENTIAL IMPACTSOF FARM TECHNOLOGIES ON RURAL ECONOMY AND SOCIETY}

In market economies it seems logical that farms will likely become much larger through extensive amalgamation, and in the process farm enterprises will increasingly mirror the corporate world of manufacturing and consumer services where scale economies are crucial. Farms can also readily benefit from scale economies, enabling skilled management to:

a. Identify and adopt technologies much earlier than in the past, although some countries like Australia have an impressive record in fast innovation in agriculture;

b. Acquire the capital to implement them speedily;

c. Hireoften expensive professional advisory services in such realms as (i) soil management (nutrients, drainage, weed infestations), (ii) best irrigation practices, (iii) animal and plant genetics, (iv) precision agriculture, (v) expert systems (e.g. crop combinations, marketing, financial management), and (vi)alternative energy supply and use; and

d. Purchase in an increasing range of contract services - machinery and equipment, harvesting, and logistics (transport of produce to markets). 
In turn, all of the above should enable (a) rising productivity of agriculture in terms of volume of output per hectare; (b) perhaps better quality of output; (c) greater certainty of supply; (d) higher average incomes for producers (farmers and their professional staff or advisors) and (e) greater environmental sustainability. Numerous authors have analysed how farm managers and business owners more generally will have to network intensively to facilitate better implementation of the above agendas. The literature includes Pentland's (2014) fascinating work on social physics, Rifkin's (2011) parallel work on the third industrial revolution in which he sees both networking and mutual sharing of resources among producers all hallmark developments of our age. Satell (2017) also focuses on the dynamics of successful innovation within businesses and institutions and, while not focusing in particular on farming, his analysis appears relevant to large-scale farm enterprises in the future. While Rifkin discusses what he sees as the third industrial revolution, Rose (2016) and Schwab (2016) talk in terms of the fourth industrial revolution. The latter see us being in the information age, which is much more than just computing and the internet. We're embracing simultaneously all the fields of inquiry listed in Table 1, and generating a vast flow of new ideas which are discussed, debated and spread rapidly, in the process overcoming barriers of space and time. Like Rifkin, but to some extent taking his ideas further, Sundararajan (2016) also sees this fourth stage as completely rewriting the nature of work and enabling the rise of crowd-based capitalism - a further extension of the sharing economy. And all this meshes with Taleb's (2012) famous work on antifragility in which all businesses, including farm enterprises, should practice optionality. This involves, among other things, scanning one's technological and commercial environment for new ways of doing things and then evaluating the costs and benefits as far as possible of alternative courses of action. This daunting task is rather easier in highly networked and interactive environments like those analysed by Pentland and Sundararajan.

Overmuch of the world since the start of the enlightenment Britain and the Netherlands in about AD 1600, cities prospered because they accelerated the pace of technological change that enabled large scale commercial industries and participated increasingly in global production and distribution systems. Their prosperity attracted peasants off the land, but those left behind often remained small-scale and impoverished producers, which is still the case in many countries. Australian agriculture increasingly belies this model and is now largely corporate in terms of administration and scale of production, with farm incomes often spectacularly high. Baldwin (2016) names Australia as one of the world's great rising economies alongside China, India, Brazil, Indonesia, Nigeria, Korea, Mexico, Venezuela, Poland and Turkey. But Australia is the only one of this group of nations to achieve its wealth on the back of large-scale primary production (farming and mining) and such services as education, medicine and tourism. See also Sorensen $(2015,2016)$ who describes the ways forward towards agile, adaptive and imaginative rural economies and societies.

However, it is worth noting that Rifkin (2011) argues that the development of what he calls the sharing economy through various kinds of voluntary local cooperatives might ensure the survival of some smaller scale producers by offering them the advantages of scale economies. For example, groups of producers might contrive to share, or mutually access, top quality machinery and equipment, good advisory services, knowledge about best farm management practices, information about what strategies work or fail, and distribution of output to market. On another track, it is not difficult to envisage massive job losses among relatively unskilled farm workers, not to forget enormous job losses arising from the arrival of driverless transport. The occupation 'driver' is one of the largest in rural areas. In contrast, we could see the rise of many highly skilled new jobs in electronics, data processing, genetics, machinery and equipment sales and maintenance, finance, distribution and marketing, and - more generally - consultant advisory services on such themes as energy supply, soil and water quality, precision agriculture and management of the natural environment. Average incomes in these specialist jobs will likely be much higher than in jobs lost, widely benefitting rural society. However, job losses and gains are unlikely to be co-located, and some rural towns and villages may become hardpressed to survive, while others prosper considerably. In practice, larger rural service 
centres are likely to be winners as they provide better education and health services; higher environmental and cultural amenity; a wider range of retail services and at lower prices; and greater spatial connectivity via transport and the internet. Such amenities appeal greatly to high income professionals [1].

The rising professionalization of the countryside can potentially increase rural incomes faster than in major cities, reversing a trend that has, in advanced economies, endured for hundreds of years. In turn, this will help rural society retain ambitious and well-educated young people and reduce the growth of large cities. Back in 2015, this author and some of his colleagues together nominated his home city of Armidale, for the Intelligent Community of the Year award based in New York and we made the top 21 out of 450 global entries. Because of Armidale's very high cultural and environmental amenity, we are attracting a wide range of high technology businesses, many concerned with agriculture and environmental management, and its population growth is now accelerating. Most of the top 21 entrants were large and prominent cities in North America, Asia, and Europe. These included New Taipei (Taiwan), San Diego (California) and Montreal (Canada). Our experience, then, is that small and relatively remote communities can challenge major cities for pre-eminence in innovation with the right mind-set and entrepreneurial capacity.

We should also note that technologies tend to have a life of their own. They are often developed privately by individuals, companies, or research institutes and, increasingly involve the blending, fusion and integration of already established technologies. More importantly, their discovery and implementation is often barely controlled by governments or society at large, except perhaps in a regulatory sense. But even then, designing effective legal environments in which technologies proceed involves much trial and error and, moreover, this process increasingly involves fraught international collaboration. So many of the prospects for agricultural innovation just described may emerge whatever governments try to do by way of regulation of farm practices.

Despite these problems, we should not understate the role of governments in easing technology-driven transformation [22]. Given that much of workers' current knowledge and skills will be invalidated by new technologies, one public responsibility entailsproviding facilities for life-long affordable practical education to update their knowledge and skills base, a task increasingly facilitated via flexible on-line delivery. Other crucial economic and social infrastructure these days includes high-speed broadband, which is central to the operation of many of impending data and information-based agricultural technologies. Remotely located Armidale has remarkably better access to high quality internet facilities than such major cities as Sydney and Brisbane, having fibre-optic cable connected to every home and business. Alas, such connectivity rapidly declines in remoter farming districts. Two years ago a House of Representatives ${ }^{1}$ Standing Committee on Industry and Agriculture conducted an inquiry into barriers to the uptake of new technologies in agriculture. I and several colleagues testified to the committee that effective farm management now requires high quality broadband for the many tasks noted earlier and our view was subsequently endorsed by the committee. People living and working in highly dispersed locations across regional Australia also face expensive and time-consuming travel to access goods and services or deliver produce to markets. Perhaps it is now time for governments to explore radically new transport systems such as the Hyperloop ${ }^{2}$ proposed by serial inventor Elon Musk, which could well be faster and cheaper than that nineteenth century technology, the railway.

In an era when technology is usurping the 'tyranny of distance', citizens are increasingly free to choose where to live and in doing so, environmental and cultural amenity is increasingly a key determinant residential choice. For example, many of Armidale's businesses are now serving national and international markets, rather than just local districts as used to be the case before greater, cheaper and more reliable connectivity was supplied by the internet. Other typical elements of amenity include (a) the preservation of important ecosystems - Armidale is adjacent to world heritage listed national parks; (b) managing dependable and high quality water supplies; (c) minimising natural hazards; (d) fostering strong cultural amenity - whether, for

\footnotetext{
${ }^{1}$ This was a committee of the Australian Federal Government located in Canberra.

${ }^{2}$ See: https://en.wikipedia.org/wiki/Hyperloop
} 
example, fine arts or the maintenance of ethnic cultures, and (e) aiding strong local social institutions. In Australia, as in many other nations, governments are also at the forefront of providing such key services as health, education and support for elderly residents. Australia has an effective system of Commonwealth and State Grants Commissions (reference) that help greatly in these tasks. Regions have different capacities to provide such services. Geography is important because (a) effective service delivery in thinly populated regions is much more expensive than in densely settled cities; (b) some areas generate much more wealth and government income than others because of their inherent high quality resources; (c) travel costs are higher in remoter locations; and so on. Australian grants commissions weigh up these advantages and constraints and allocate extra resources to handicapped regions through a process of what one might term fiscal equalisation or interregional subsidy.

Such redistribution of government incomes is likely to become much more important in coming years as technological revolution revises drastically the wealth and competitive power of different places, especially in rural areas. Even then, many communities may lose completely their raison d'être and in such cases governments may be faced with the task of place euthanasia. In effect, this means shutting down a settlement and helping residents move to another location with much better services and brighter prospects.

\section{CONCLUSION}

Technologies of the kinds discussed could dramatically change rural economy and society everywhere, with considerable benefits including greater rural income \& wealth, per capita productivity, important growth in food and fibre production, and more sustainable environments. But, here are two key questions. How can we ensure that we maximise the benefits from early adoption of new technologies but also minimise the damage done to those harmed by imminent changes? The answers seem clear to me. Both questions require the mass modification of human behaviours to create societies that are future oriented, risk accepting, experimental, strongly networked (for both ideas generation and mutual support), highly educated in both academic (research/ new knowledge) and skills acquisition senses, supplied with abundant risk capital, tolerant of failure, ability to learn from experiences and change course, and so on. This is the culture of Silicon Valley and the world's other high-tech nodes, as noted earlier. And such culture shifting on a grand scale is the goal of a network of community activists in my home town, Armidale. Alas, most senior tiers of government have little or no experience of laying communities down on the psychologist's couch, diagnosing behavioural weaknesses in readily adopting new technologies, and recommending effective processes for behavioural rectification. My colleagues and I are trying to embrace this task from the bottom up, inventing processes as we learn from our mistakes - a task that is termed place-based economic development in a substantial new literature [3].

In short, technological transformation is not just a threat to current agricultural practices and dependent communities, but also to the whole of government and society. We must find new and imaginative ways of dealing on the one hand with problems arising and, on the other, with encouraging adaptive and agile change. All this is becoming more difficult on many conflicting and inter-woven grounds. Accelerating change creates massive uncertainty about where we're headed and creates tension between sections of the community who are fearful or welcoming of the future. Management of the transition to new and undefined futures is also made much more difficult by rising systemic complexity: the increasing number of operational variables in play, difficulties in specifying their interconnections, and absence of reliable data to understand what is going on. In a fast changing system, data age rapidly and become increasingly irrelevant. So, how do we handle monolithic turmoil where many different actors are engaged in a furious trial and error process across all spatial scales of economy, society and polity?

The answer must rest in dynamic mutual conversation amongst all diverse relevant interests, much like the future is being invented in the world's leading technology hubs by huge networks of entrepreneurial people bristling with new ideas. In their environment many new businesses are established, most of which fail. The failure rate of start-up enterprises in Silicon Valley is estimated at $85 \%$ ! Who cares? We learn from exchanging ideas about what works or fails and why those outcomes occur. Perhaps farmers 
and their dependent settlements should likewise focus heavily on exchanging ideas about successes and failures from their endeavours and learning from their collective experiences. An organisation called the Australian Smart Communities Association (ASCA) is attempting such a strategy for towns and cities across the nation and perhaps this should be developed in parallel across rural society. While Shakespeare, in my introductory quotation, four centuries ago derided the relevance of the past to guiding the future, it is interesting to note that a key philosopher of the $21^{\text {st }}$ century is possibly Michel de Montaigne (1580)! His Essais advocate people and organisations being guided by learning from experience, noting which actions or strategies appear to work or fail and why that is the case. Of course, in today's world we are drenched by a continuous downpour of reports on experiences, but the more we discuss and make sense of them, the more we are likely to develop effective collective or individual responses to the tsunami of change that we confront. To embrace the ancients yet ago it's also worth noting that Plato, in his dialogue - Critias (c. 375 BC), sees two worlds: an immanent world of being, and a shifting world of becoming. He, Plato, couldn't envisage however that we now inhabit a world that is almost all 'becoming'! Recognising this will be a game-changer for the conduct of human affairs.

\section{REFERENCES}

[1]. N. Argent, M. Tonts, R. Jones and J. Holmes, "A creativity-led rural renaissance? Amenity led migration, the creative turn, and the uneven development of rural Australia", Applied Geography, Vol. 44, pp. 88-98, 2013.

[2]. Baldwin, R. 2016. The Great Convergence: Information Technology and the New Globalization. Cambridge, Mass: Harvard University Press.

[3]. F. Barca, P. McCann and Rodríguez-Pose, "The case for regional development intervention: place-based versus place-neutral approaches", Journal of Regional Science, Vol. 52, issue 1, pp.134-152, 2012.

[4]. Brin, D. \& Bear, G. 2015. Visions of the Future. Minden, NV: Lifeboat Foundation.

[5]. Brockman, J. 2017. Know This: Today's Most Interesting and Important Scientific Ideas, Discoveries, and Developments. New York: Harper Collins.

[6]. Brynjolfsson, E. and McAfee, A. 2014. The second machine age: Work, progress and prosperity in a time of brilliant technologies. New York: Norton.

[7]. Diamandis, P. and Kotler, S. 2012. Abundance: The Future Is Better Than You Think. New York, Free Press.
[8]. Ford, M. 2009. The lights in the tunnel: Automation, accelerating technology and the economy of the future. Acculant Publishing.

[9]. Greengard, S. 2015. The internet of things. Cambridge, MA: MIT Press.

[10]. Hammersley, B. 2012. 64 things you need to know now for then. Sydney, Australia: Hodder.

[11]. Heck, S. and Rogers, M. 2014 Resource Revolution: How to capture the biggest business opportunity in a century. Melcher Media: New York

[12]. Kellmereit, Daniel and Obodovski, Daniel. 2013. The Silent Intelligence - The Internet of Things. San Francisco, Ca: DnD Books.

[13]. Leonard, Gerd 2016. Technology vs Humanity: The Coming Clash between Man and Machine. London: Fast Future Publishing Ltd.

[14]. Mills, D. 2013. Our uncertain future: When digital evolution, global warming and automation converge. San Diego, CA: Pacific Beach Publishing.

[15]. de Montaigne, M. 1580. Essais. Bordeaux: Simon Millanges.

[16]. Pentland, A. 2014. Social physics: How good ideas spread. New York, NY: The Penguin Press.

[17]. Rifkin, J. 2011. The third industrial revolution: How lateral power is transforming energy, the economy, and the world. London: Palgrave MacMillan.

[18]. Rose, G. (ed.) 2016. The Fourth Industrial Revolution: A Davos Reader. Foreign Affairs.

[19]. Ross, A. 2016. The Industries of the Future. Simon and Schuster, New York.

[20]. Satell, G. 2017. Mapping Innovation: A Playbook for Navigating a Disruptive Age. McGraw Hill, NY.

[21]. Schwab, K. 2016. The Fourth Industrial Revolution. World Economic Forum.

[22]. Sorensen, A. 2015.The Future of Regional Australia: Change on our terms. Regional Australia Institute Discussion Paper, Canberra, November.

[23]. Sorensen, A. 2017. Australia: Community Development in an Age of Mounting Uncertainty: Armidale, Australia [in] G. Halseth (Ed.) Transformation of Resource Towns and Peripheries: Political economy perspectives, Routledge, New York, pp. 248 - 267.

[24]. Sundararajan, A. 2016. The Sharing Economy: The end of employment and the rise of crowd-based capitalism. Boston, Mass: MIT Press,

[25]. Susskind, R and Susskind D. 2016. The Future of the Professions: How technology will transform the work of human experts. Oxford University Press, USA.

[26]. Taleb, N. 2012. Antifragile: Things that gain from disorder. London: Penguin.

[27]. Wadhwa, V. and Salkever, A. 2017. The Driver in the Driverless Car: How Our Technology Choices Will Create the Future. Berrett Koehler Publishers Inc. Oakland, CA.

[28]. de Waele, R. 2014. Shift 2020: How technology will impact our future. Kindle Version.

[29]. Wood, D. (ed.) 2014. Anticipating 2025: A guide to the radical changes that may lie ahead, whether or not we're ready. London Futurists 


\title{
Cách mạng công nghiệp trong nông nghiệp: những điều gợi ý cho tái cấu trúc kinh tế xã hội nông thôn
}

\author{
Anthony Sorensen \\ Đại học New England (Úc) \\ Email tác giả liên hệ: Tony.Sorensen@une.edu.au
}

Ngày nhận bản thảo: 01-12- 2017; Ngày chấp nhận đăng: 22-12-2017; Ngày đăng: 30-6-2018

Tóm tắt-Chúng tôi xác định nhiều công nghệ hiện đại có khả năng tác động mạnh mẽ đến hầu hết các khía cạnh của kinh tế, xã hội và môi trường nông thôn, thậm chí trong ngắn hạn. Kết quả, hai vấn đề xã hội chính yếu đang bị che khuất (a) cách tốt nhất để đẩy nhanh sự phát triển các công nghệ có lợi, trong khi (b) đang giúp đõ các các nhân, cộng đồng hay những nơi bị thiệt hại bởi một chuỗi các sự kiện - ví như việc cập nhật kỹ năng của con người và xem xét lại những tham vọng cũng như sở thích của họ. Vấn đề ngày càng khiến chính phủ, cộng đồng và các doanh nghiệp quan tâm chính là việc chúng ta có quá ít tri thức về nền kinh tế trong tương lai và quỹ đạo xã hội được điều khiển bởi những công nghệ này. Do đó, những hoạch định chi tiết truyền thống sẽ càng dư thừa, trong khi những hướng đi có tác động đến tương lai sẽ đòi hỏi những luận bàn và tranh luận mạnh mẽ xoay quanh những chọn lựa tốt nhất cùng với sự lãnh đạo mạnh mẽ sẽ giúp sức cho những nền văn hóa sáng tạo, linh động và đầy tính thích ứng. Sự đa dạng thuộc về địa lý trong tài nguyên thì hoàn toàn có thể nổi lên những chiến lược tối ưu biến đổi từ nơi này sang nơi khác.

Tù̀ khóa-công nghệ biến đổi xã hội và kinh tế nông thôn, văn hóa sáng tạo linh động và thích ứng, hỗ trọ̣ những người và khu vực có thể bị tổn hại bởi sự thay đổi kinh tế 